\title{
CHEMICAL GOMPOSITION OF UTILITY WATER IN THE ARID CLIMATE ZONE ON THE EXAMPLES OF KÉBILI AND MEDENINE REGIONS (SOUTHERN TUNISIA)
}

\author{
Beata Latos, Karolina Sobczak-Szelc, Krzysztof Skocki, \\ Rafat Koztowski, Anna Szczucinska
}

\begin{abstract}
Areas located within the hot, arid zone are characterized by extremely low availability of fresh water. In the Tunisian regions of Kébili and Medenine, deep-water sources and connate groundwater constitute its main sources. Surface waters, as well as shallow groundwaters found in those areas, are affected by a high level of salinity, which significantly reduces their use for either drinking or agriculture. Due to intensifying droughts the rainwater accumulation system, neither fulfils the needs of residents nor the developing agriculture. Waters in the oases of El Faour (Kébili) and Beni Kchedeche (Medenine) were analyzed in 2017 to find out their chemical composition, as well as their suitability for irrigation. The chemical composition of the investigated waters is dominated by the $\mathrm{Na}^{+}, \mathrm{Ca}^{2+}, \mathrm{Cl}^{-}$and $\mathrm{SO}_{4}^{3-}$ ions. The value of electrolytic conductivity (EC) was found to be within the range of 1100 to $6400 \mu \mathrm{S} / \mathrm{cm}$. The highest concentration of nitrate was $44 \mathrm{mg} / \mathrm{L}$. Salinity indicators classified this water mainly as unsuitable for irrigation on the basis of sodium adsorption ratio (SAR) and EC, sodium total percentage $(\% \mathrm{Na})$ and Kelly's ratio (KR). The iron concentration in all examined wells exceeded the recommended values set for potable water and ranged from 0.6 to $2.5 \mathrm{mg} / \mathrm{L}$.
\end{abstract}

Keywords: hydrochemistry, groundwater, salinity, arid zone, SAR

\section{Introduction}

The aquatic resources in North Africa are under strong pressure. Global changes include climate changes and modifications of land use, caused mainly by population 
growth which, amongst others, contributes to increased demand for water (Agoune 2010; Diekkrüger et al. 2012). The arid climate zone is an area that is vulnerable to problems with water, in terms of its quantity and quality. The Sahara Desert and the Sahel zone disclose a variable but still high vulnerability to climate changes occurring both today and in the past (Lézine et al. 2011). Extremely little access to fresh water, with either low or average mineralization in the surface water, results in extensive use of groundwater, which is excessively exploited and sensitive towards the ongoing climate and ecosystem changes. Over the last several years there has been a significant decrease in the level of groundwater, which poses difficult accessibility of water for the needs of the local population, as well as the irrigation of surrounding farmlands. Limited water resources have become a factor that inhibits socio-economic development (Agoune 2010; Mekki et al. 2013). This is very important from an economic point of view - reduced is water for local agriculture, drinking, as well as for the surrounding ecosystem - the lowering of the groundwater table leads to a number of negative consequences, including desertification of the adjacent areas. This, in turn, reduces the possibilities of using those areas by man (Le Houerou 2010).

In the context of the multi-faceted problem of the destructive impact that human economic activities have on the natural environment, it is particularly important to indicate pollution of both groundwater and surface water. Physical and chemical properties of groundwater are important for the environment because they affect components such as soil and other qualities that remain under its influence. At the same time, in many places one can recognize significant changes in the quality and quantity of water as a result of strong anthropogenic pressure. The quality of water, both surface and groundwater, in Tunisia is constantly polluted by domestic and industrial sewage, leaching of fertilizers and plant protection pesticides from the soil (Le Houerou 2010; Abdallah et al. 2008). This all contributes to the significant increase in groundwater salinity (Rahaingomanana 1999; Zammouri et al. 2007).

The hydrochemical properties of water in the arid zone are a topic frequently presented. Nonetheless, there are still places where the physical and chemical properties of water, especially groundwater, are yet to be determined. There is a clear and increasing need to establish a cyclic groundwater-monitoring network in regions of its intensive exploitation (Hamzaoui-Azaza et al. 2011; Boulbaba et al. 2012). Therefore, to address the constant changes observed in the underground environment, in the investigated region we conducted the research on the physical and chemical properties of groundwater. The aim of the study was to identify the processes and factors that affect the characteristics of groundwater and to assess its suitability for agricultural purposes. 


\section{Study area}

The investigated areas are located in southern Tunisia and cover the areas of Kébili and Medenine Governorates (Fig. 1). According to Köppen-Geiger classification, both investigated areas are located in low latitude desert climate (BWh - Dry Arid Low Latitudes) (Peel et al. 2007). The climate is hot and very arid, with an average annual rainfall of 50 to $200 \mathrm{~mm}$. Although very irregular and rare it may be very intense. Evaporation greatly exceeds precipitation, due to the prevalence of orographic barriers in the form of latitudinal mountain ranges. The region of El Faouar witnesses even less precipitation with an average of 50-100 mm annually. In winter, air circulation is conditioned by the occurrence of Mediterranean lows, Saharan highs, and Azores highs. In summer, the circulation is conditioned by the presence of high pressure over the Sahara Desert as well as Azores High. The average annual temperature is approximately $25^{\circ} \mathrm{C}$ (Agoune 2010). During hot summers

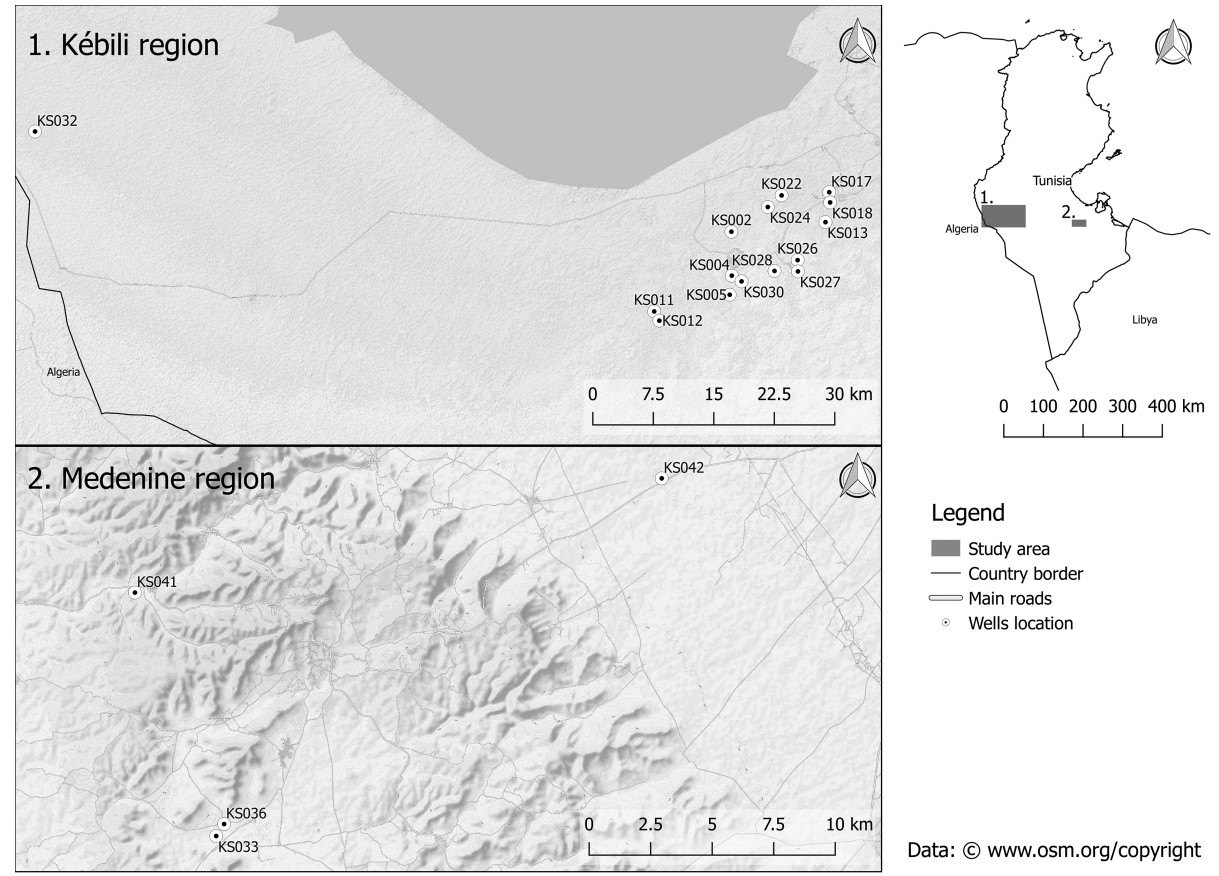

Fig. 1. Location of the study area together with the investigated water drawing points, 1 - Kébili region, 2 - Medenine region 
the maximum temperature is able to reach $55^{\circ} \mathrm{C}$ (July), during winter the minimum temperature falls to $7^{\circ} \mathrm{C}$ (December) (Mouldi 2003).

The investigated areas differ in terms of geology. In El Faouar region in the Kébili Governorate, the geology is composed of sedimentary rocks from the Paleogene and Neogene periods (primarily Oligocene and Pliocene epochs). These mostly include aeolian deposits in the form of wind-blown sand and sand dunes of natural heights not exceeding approximately 5 meters. They constitute part of the Great Eastern Sand Sea. Sediments with variable thickness, from several to several dozens of meters, are underlain with solid rocks largely of marine origin - (limestone and gypsum). The sand is averagely or well sorted out due to the almost permanent occurrence of winds, and therefore the aeolian transport as well. This creates sequential patches of wind-blown sands and dunes, mostly complex systems of transverse and longitudinal sand dunes. Typical for this area is to find a layer of sand cemented with mineral salts and gypsum at small depths, usually several tens of centimetres below ground level. This layer is hard and has the possibility to constitute a low permeable layer that stops rainwater and protects it from direct evaporation near the surface and the soil. However, dissolving salts can lead to strong salinity of such periodic water bodies and when combined with capillary infiltration and uptake of water by the root systems of plants, it can contribute to the salinity of the surface layers of soil, which can be noticed through satellite images of particular oases. The soils of this area are classified as Aridisols. However, it is also possible to find Salids, Argids and Gypsids as well as Calcids soils. The presence of gypsum and high salinity contributes to corrosion (Agoune 2000). The mobile and light desert sands of the Great Oriental Sand Sea are blown onto the formed soil.

The second region of Beni Khedeche in Medenine Governorate is located in the central part of the Matmata Mountains, which constitute an insulated, longitudinally-stretched massif. This massif extends over a length of almost $150 \mathrm{~km}$ and has a maximum width of approximately $35 \mathrm{~km}$. In geological terms, it is composed of carbonate rocks from the Jurassic and Triassic periods. In terms of facies it is built from Bhir Formation (gypsum and anhydrite), Zmilet Haber (dolomites rich in coprolite) and Mastaoua (evaporites and dolomites) of the Upper Triassic, underlain with Merbah el Asfer Formation followed by Krachuoa Formation (slates, carbonates and conglomerates and sometimes dolomitic sandstones), Techout (clays, dolomites and sandstones) and Foum Tataouine (limestones and sandstones) from the Middle Triassic period (Tawadros 2011).

Access to potable water in southern Tunisia is limited and periodically varying. The following irrigation systems are used depending on the region: use of connate underground water, use of rain and surface water as well as shallow aquifers supplied by infiltration. The central and southern parts of the country are occupied by endorheic areas partly covered by chotts supplied by periodic rivers. There 
is an abundance of artesian water with potent sources. Two fundamental artesian water among those deeply located in southern Tunisia are distinguished: the first from the lower Cretaceous period located in a layer of sandstone, and the second located in the limestone layer from Upper Cretaceous that supplies the Jerid and Rhasa chotts. These huge aquifers range with theoretical water catchment areas are estimated respectively between 600 and 320 thousand $\mathrm{km}^{2}$. This extends far beyond the borders of Tunisia and reaches Algeria, Libya and even western Egypt (Dłużewski 2004 after Gouskov 1952; Drouhin 1953). Such natural conditions result in the fact that water drawn in oases is derived mainly from aquifers. This water is used mainly for drinking, sanitary and living purposes as well as agricultural irrigation and water for livestock. Furthermore, agriculture in the study area is closely dependent on the availability of groundwater (region of Kébili) and rainfall (region of Medenine). Due to the intensifying droughts, farmers willing to develop agriculture in the second described region are forced to seek additional sources of irrigation, i.e. groundwater. During the last years it has been noticed that the groundwater has significantly lowered due to increased abstraction, caused by population growth, intensifying droughts and progressive reduction in the quality of these water (Mekki et al. 2013).

Due to the large depth of groundwater placement, high evaporation rate and salinity of soil, vegetation that can be found naturally in the area is relatively scarce. In order to give sufficient crops, fields required irrigation. Main crops cultivated in the Kébili region include plants from the Arecaceae family mostly date palms (Phoenix dactylifera L.). In turn, in the Medenine region main cultures constitutes olive trees (Olea europaea L.). In addition, lucerne, barley, wheat, legume, vegetables and herbs are cultivated as well, however only for household needs.

\section{Methods}

The ten drilled wells (11 water samples) reaching groundwater at depth of 50 to $250 \mathrm{~m}$, four artesian wells (samples from the depth range of 80-115 m), two wells (three water samples) reaching geothermal water from "Continental Intercalaire" level at depth around $1500 \mathrm{~m}$ and one digged well, were sampled.Apart from geothermal water regarding which there was no possibility to measure temperature, all of them were in field covered with basic measurement of physicochemical parameters of groundwater such as temperature (T), specific electrical conductivity (EG), and pH. EC and T were measured with a conductivity meter (CC-401, Elmetron), with automatic compensation to a reference temperature of $25^{\circ} \mathrm{C}$ and accuracy of $\pm 1 \%$ and $\pm 1^{\circ} \mathrm{C}$, respectively. The $\mathrm{pH}$ was measured with a $\mathrm{pH}$ meter (CP-411, Elmetron), with an accuracy of $0.01 \mathrm{pH}$ units. Water samples were taken from all wells for further 
laboratory analyses. All the samples were collected in tight capped, polyethylene bottles and stored refrigerated.

Prior to analyses, the samples were filtered through the Whatman glass microfiber filter (filter size: $25 \mathrm{~mm}$, pore size: $0.45 \mu \mathrm{m}$ ). Cations $\left(\mathrm{Ca}^{2+}, \mathrm{Mg}^{2+}, \mathrm{K}^{+}, \mathrm{Na}^{+}, \mathrm{NH}_{4}^{+}\right.$, and $\left.\mathrm{Li}^{+}\right)$and anions $\left(\mathrm{Cl}^{-}, \mathrm{SO}_{4}{ }^{2-}\right.$, and $\mathrm{NO}_{3}^{-}$) concentrations were measured by ion chromatography with ICS 3000 (Dionex), including 3x250 mm IonPac CS16 and 2x250 mm IonPac AS18 analytical columns for cations and anions, respectively. Elements (Al, As, Cd, Co, Cr, Cu, Fe, Mn, Ni, Pb, Sr, and Zn) were determined by inductively coupled plasma time-of-flight mass spectrometry (ICP-MS-TOF) with GBC OptiMass 9500. Bicarbonates $\left(\mathrm{HCO}_{3}^{-}\right)$were analyzed by titration. Detection limits amounted to: $0.4 \mathrm{mg} / \mathrm{L}$ for $\mathrm{Ca}^{2+}, 0.2 \mathrm{mg} / \mathrm{L}$ for $\mathrm{Mg}^{2+}, \mathrm{Na}^{+}, \mathrm{NH}_{4}^{+}$, and $\mathrm{Li}^{+}$, $0.1 \mathrm{mg} / \mathrm{L}$ for $\mathrm{K}^{+}$, and $0.01 \mu \mathrm{g} / \mathrm{L}$ for trace elements.

Hydrochemical results for all samples were statistically analyzed (Timm 2002; Härdle, Simar 2003) with the statistical software IBM SPSS Statistics 24. Since the data showed normal distribution, the Pearson linear correlation coefficient $(r)$ was calculated to evaluate correlations between the variables. Cluster analysis was used to search for patterns in the data set by grouping the (multivariate) observations into clusters. The goal was to find an optimal grouping for which the observations or objects within each cluster were similar, but the clusters were dissimilar to each other. Clustering was based on complete-linkage clustering and Euclidean distance. The water quality of each sample was plotted on a classical Piper diagram, referring to the concentrations (meq/L) of hydrochemical components (Piper 1944). This diagram provides a convenient method to classify and compare water types based on the ionic composition of different water samples (Hem 1985).

To validate the possibility of using the water for irrigation, the sodium adsorption ratio (SAR) was calculated, with the following formula (1):

$$
S A R=\frac{N a}{\sqrt{\frac{C a+M g}{2}}}
$$

Where chemical concentrations are reported in meq/L (Ciaccio 1971). We have also applied:

- sodium total percentage $(\% \mathrm{Na})$, calculated with the use of the formula (2). The $\mathrm{Na}^{+}, \mathrm{Ca}^{2+}, \mathrm{Mg}^{2+}$ and $\mathrm{K}^{+}$ions concentration expressed as meq/L.

$$
N a=\frac{\left(N a^{+}+K^{+}\right) \cdot 100}{\left(C a^{2+}+M g^{2+}+K^{+}\right)}
$$


- permeability index (PI) calculated with the use of the formula (3) according to Ragunath (1987). The $\mathrm{Na}^{+}, \mathrm{Ca}^{2+}, \mathrm{Mg}^{2+}$ ions and $\mathrm{HCO}_{3}^{-}$concentration is expressed as $\mathrm{meq} / \mathrm{L}$.

$$
P I=\frac{\left(\mathrm{Na}^{+}+\sqrt{\mathrm{HCO}_{3}^{-}}\right)}{\mathrm{Ca}^{2+}+\mathrm{Mg}^{2+}+\mathrm{Na}^{+}} \cdot 100
$$

- Kelly's ratio (KR), calculated with the use of the formula (4) proposed by Kelly (1963). The $\mathrm{Na}^{+}, \mathrm{Ca}^{2+}, \mathrm{Mg}^{2+}$ ions concentration is expressed as meq/L.

$$
K R=\frac{N a^{+}}{\left(C a^{2+}+M g^{2+}\right)}
$$

- magnesium hazard indicator (MH), calculated according to Szabolcs and Darab (1964) (5). The $\mathrm{Ca}^{2+}, \mathrm{Mg}^{2+}$ ions concentration is expressed as meq/L.

$$
M H=\frac{M g^{2+}}{\left(C a^{2+}+M g^{2+}\right)} \cdot 100
$$

The type of ion exchange was deduced from the base exchange index (BEI), given by the following formula expressed as meq/L (6):

$$
B E I=\frac{C l^{-}-\left(N a^{+}+K^{+}\right)}{C l^{-}}
$$

BEI $<0$ indicates fixation of $\mathrm{Ca}^{2+}$ and $\mathrm{Mg}^{2+}$ and solubilization of $\mathrm{Na}^{+}$and $\mathrm{K}^{+}$. BEI $>0$ indicates fixation of $\mathrm{Na}^{+}$and $\mathrm{K}^{+}$and solubilization of $\mathrm{Ca}^{2+}$ and $\mathrm{Mg}^{2+}$.

\section{Results}

A detailed description of the wells from which the water was drawn for further analysis is presented in Table 1 together with the results of the ground temperature measurements, electrical conductivity and $\mathrm{pH}$.

Water in wells up to $300 \mathrm{~m}$ depth were characterized by temperature ranging from $22.8^{\circ} \mathrm{C}$ to $28.4^{\circ} \mathrm{C}$. Since the direct access to thermal water was limited, the measurements of its temperature are burdened with a significant error margin. On the basis of interview and organoleptic checks, it can be estimated that the temperature exceeds $70^{\circ} \mathrm{C}$. The $\mathrm{pH}$ values ranged from 4.5 to 6.5 and 7.0 in dug well. Electrical conductivity was characterized by a diversity amongst individual wells and ranged 
Table 1. Characteristics of the investigated water samples and their fundamental physicochemical properties

\begin{tabular}{|c|c|c|c|c|c|c|c|c|}
\hline Sample ID & Co-ordinates N & Co-ordinates $\mathrm{E}$ & $\begin{array}{l}\text { Altitude } \\
\text { [m a.s.l.] }\end{array}$ & Type of well & $\mathrm{T}\left[{ }^{\circ} \mathrm{C}\right]$ & $\mathrm{pH}$ & $\begin{array}{c}\mathrm{EC} \\
{[\mathrm{mS} / \mathrm{cm}]}\end{array}$ & $\begin{array}{c}\text { Depth } \\
\text { [m b.s.l.] }\end{array}$ \\
\hline KS004 & $33^{\circ} 20^{\prime} 24.1^{\prime \prime}$ & 8'40'06.7" & 72 & $\begin{array}{l}\text { Drilled well with } \\
\text { geothermal water }\end{array}$ & $\sim 70.0$ & 5.0 & 3.81 & $\sim 1500$ \\
\hline KSO05* & $33^{\prime} 20^{\prime} 24.1 ”$ & $8^{\circ} 40^{\prime} 06.7^{\prime \prime}$ & 72 & $\begin{array}{l}\text { Drilled well with } \\
\text { geothermal water }\end{array}$ & 39.0 & 5.0 & 3.91 & $\sim 1500$ \\
\hline $\mathrm{KSO} 32^{* * *}$ & $33^{\circ} 29^{\prime} 3.0^{\prime \prime}$ & 7'42'8.0" & 23 & $\begin{array}{l}\text { Drilled well with } \\
\text { geothermal water }\end{array}$ & 31.0 & 6.5 & 3.18 & $\sim 1500$ \\
\hline KS002 & $33^{\prime} 22^{\prime} 33.5^{\prime \prime}$ & 8'41'08.6"' & 39 & Drilled well & 24.5 & 4.5 & 2.65 & nd \\
\hline KS013 & $33^{\circ} 23^{\prime} 9.5^{\prime \prime}$ & 8'49'22.2"' & 34 & Drilled well & 26.0 & 6.5 & 1.98 & 135 \\
\hline KS017 & $33^{\circ} 26^{\prime} 00.3^{\prime \prime}$ & 8'48'44.2" & 28 & Drilled well & 25.0 & 6.0 & 2.48 & $\sim 250$ \\
\hline KS018** & $33^{\circ} 26^{\prime} 06.3^{\prime \prime}$ & 8'49'16.3"' & 43 & Drilled well & 25.0 & 6.0 & 2.47 & $\sim 250$ \\
\hline KSO26 & $333^{\circ} 21^{\prime} 31.8$ '” & 8'45'26.3" & 56 & Drilled well & nd & nd & 2.02 & 180 \\
\hline KS027 & $33^{\circ} 20^{\prime} 49.4^{\prime \prime}$ & $84^{\circ} 53.7 "$ & 44 & Drilled well & 24.0 & 5.0 & 2.43 & $\sim 200$ \\
\hline KS028 & $33^{\circ} 21^{\prime} 00.1^{\prime \prime}$ & 8'44'17.3"' & 44 & Drilled well & 24.0 & 6.0 & 2.16 & 180 \\
\hline KS033 & $33^{\circ} 10^{\prime} 49.0^{\prime \prime}$ & $10^{\circ} 9^{\prime} 26.9^{\prime \prime}$ & 394 & Drilled well & 23.0 & 6.5 & 6.40 & 130 \\
\hline KS036 & $33^{\circ} 11^{\prime} 04.7 \prime$ & 10'09'39.3"' & 398 & Drilled well & nd & nd & 5.52 & 135 \\
\hline KS041 & $33^{\circ} 16^{\prime} 08.1^{\prime \prime}$ & 10'07'19.5" & 457 & Drilled well & nd & nd & 1.91 & 50 \\
\hline KS042 & $33^{\circ} 18^{\prime} 37.7^{\prime \prime}$ & $10^{\circ} 21^{\prime} 05.6 "$ & 156 & Drilled well & 28.4 & 6.5 & 1.10 & 90 \\
\hline KS011 & $33^{\circ} 17^{\prime} 30.5^{\prime \prime}$ & $84^{\prime} 03.1^{\prime \prime}$ & 35 & Artesian well & 24.0 & 5.0 & 2.05 & 84 \\
\hline KS012 & $33^{\circ} 17^{\prime} 27.4 "$ & 8‘34'02.9”' & 35 & Artesian well & 24.0 & 5.0 & 2.13 & 84 \\
\hline KS022 & $33^{\circ} 25^{\prime} 50.3^{\prime \prime}$ & 8“43'26.1" & 18 & Artesian well & nd & 5.0 & 2.68 & nd \\
\hline KS024 & $33^{\circ} 25^{\prime} 29.9^{\prime \prime}$ & 8'43'16.1" & 27 & Artesian well & 22.8 & 5.0 & 1.94 & 114 \\
\hline KS030 & $33^{\circ} 22^{\prime} 20.0^{\prime \prime}$ & $80^{\circ} 58.0^{\prime \prime}$ & 17 & Digged & 24.0 & 7.0 & 14.31 & 2.20 \\
\hline
\end{tabular}

Explanations: T - water temperature, EC - electrical conductivity, nd - no data, * - KS004 and KS005 represent the same well, however one sample was taken at the top of the tower (KS004) and the second at its bottom (KS005), ** - KS017 and KS018 represent the same well, however one sample was taken at the point of outflow (KS018) and the second $500 \mathrm{~m}$ further at the point of entry to the fields area (KS017), *** - well located in the administrative borders of the Tozeur Governorate, incorporated into the analysis in view of the small number of bore-holes to geothermal water at a depth of $\sim 1500 \mathrm{~m}$. 
from $1.10 \mathrm{mS} / \mathrm{cm}$ to $14.31 \mathrm{mS} / \mathrm{cm}$. The highest value of electrical conductivity was measured in the single dug well. The maximum for the others reaches $6.40 \mathrm{mS} / \mathrm{cm}$. The results of the laboratory along with descriptive statistics can be found summarized in Table 2.

Analysis of the main ions that constitute the chemical composition of water determines the Na-Ca-Cl-SO $\mathrm{S}_{4}$ hydrochemical type of water prevailing in this area. Piper Diagram (Fig. 2) indicates the hydrochemical types of the tested wells. Four of the studied wells have a different hydrochemical type. Three wells, KS030, KS033 and $\mathrm{KS} 036$ have the type $\mathrm{Na}-\mathrm{Cl}-\mathrm{SO}_{4}$, and well $\mathrm{KS} 042$ is characterized by a complex type $\mathrm{Na}-\mathrm{Ca}-\mathrm{HCO}_{3}-\mathrm{Cl}-\mathrm{SO}_{4}$.

Calculated indicators used for evaluating the suitability of water for irrigation are shown in Table 3.

The obtained results constitute the basis for interpreting the factors that contribute to the chemistry of utility water in the area of southern Tunisia. The suitability of water for irrigation purposes was discussed as well.

\section{Discussion}

The research conducted in southern Tunisia indicate a high degree of similarity amongst the chemical properties and the analyzed groundwater. The $\mathrm{Na}-\mathrm{Ca}-\mathrm{Cl}-\mathrm{SO}_{4}$ hydrochemical type of water prevailing for this region is frequently found in arid climate regions (Charef et al. 2009; Hamzaoui-Azaza et al. 2011; Lachaal et al. 2013; Alaya et al. 2016). This is due to the presence of evaporites which are dissolved by groundwater. Halite is the most frequent manner of enhancing water with $\mathrm{Na}$ and Cl ions (i.e. Farhat et al. 2010; Warner et al. 2013). It can be easily and quickly dissolved. In case of the 14 wells the BEI is $>0$ ('Table 4), which indicates replacement of $\mathrm{Na}$ and $\mathrm{K}$ ions with $\mathrm{Ca}$ and $\mathrm{Mg}$, contributing to the presence of $\mathrm{Ca}$ ions in water which constitute over $20 \%$ mval.

The source of $\mathrm{SO}_{4}$ ions in water is also the solubilization of evaporites, primarily gypsum, as indicated by the high correlation coefficient between $\mathrm{SO}_{4}{ }^{2-}$ a $\mathrm{Sr}^{2+}$ amounting to $r=0.99$ (Fig. 3). Waters in the studied area show similarity to other waters of this region (Hassine et al. 2013). This is mainly due to low rainfall, high evaporation and the presence of gypsum-enriched soils.

An abnormal concentration of iron was recognized in the analyzed water. No guideline value for iron in drinking water is proposed by WHO (WHO, 2017), however, high iron content impairs organoleptic properties, mainly the taste of water. The average content of iron compounds in drilled and artesian wells was $1.3 \mathrm{mg} / \mathrm{L}$. A significantly higher concentration was observed in a shallow digged well, as it was close to $7 \mathrm{mg} / \mathrm{L}$. The analyzed wells indicated the increased content of nitrates, the 


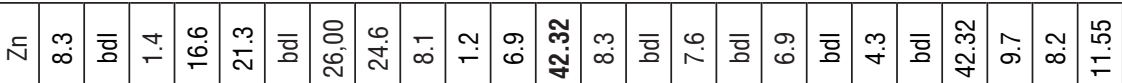

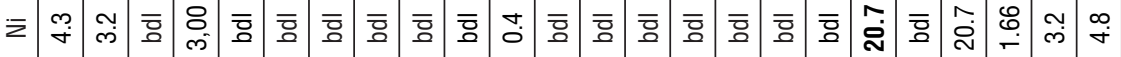

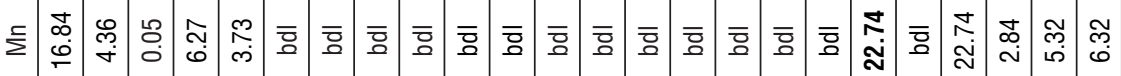

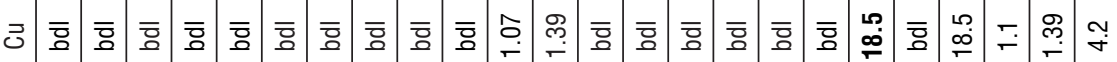

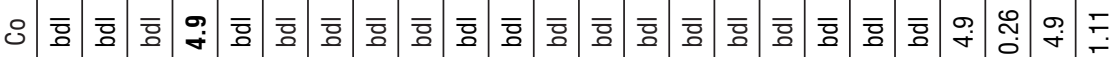

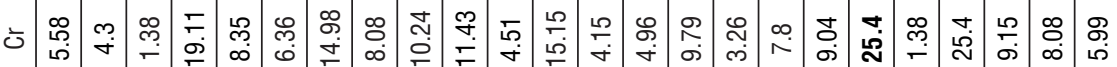

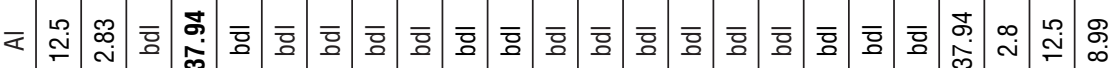

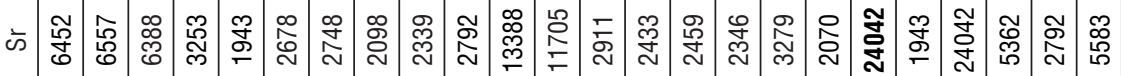

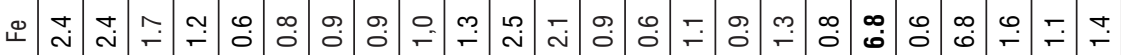
m

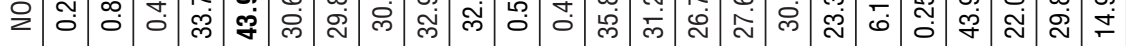

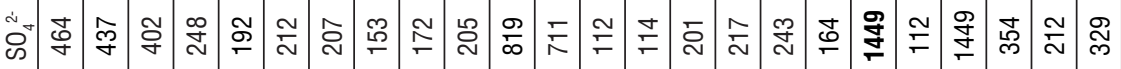

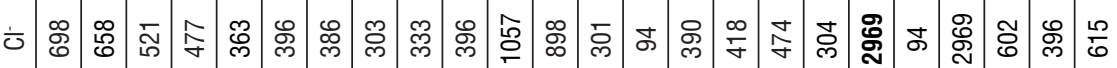
宅 \& 荧

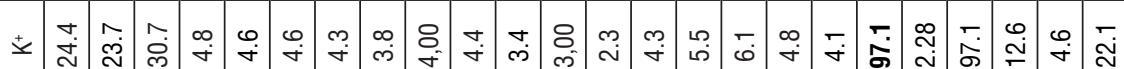
+ 㐫

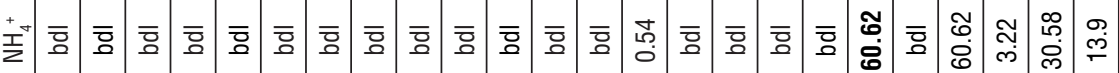

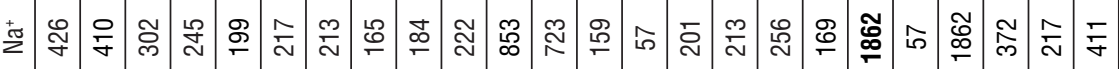

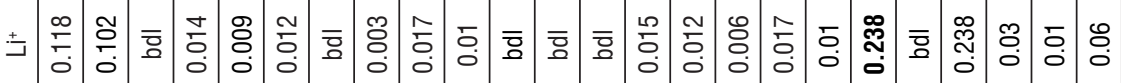

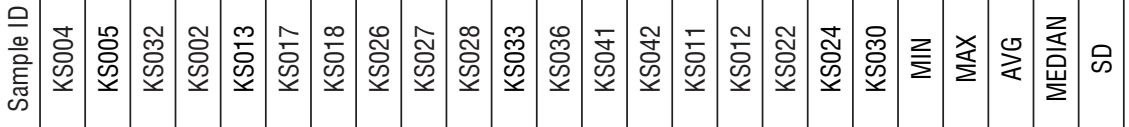


Table 3. Indicators for the evaluation of suitability of groundwater from the regions of Kébili and Medenine for irrigation

\begin{tabular}{|c|c|c|c|c|}
\hline Sample ID & $\%$ Na & KR & MH & PI \\
\hline KS004 & 62 & 1.61 & 24 & 64 \\
\hline KS005 & 62 & 1.55 & 23 & 64 \\
\hline KS032 & 61 & 1.48 & 22 & 63 \\
\hline KS002 & 55 & 1.20 & 36 & 59 \\
\hline KS013 & 58 & 1.36 & 36 & 63 \\
\hline KS017 & 60 & 1.49 & 37 & 65 \\
\hline KS018 & 62 & 1.59 & 38 & 67 \\
\hline KS026 & 59 & 1.39 & 31 & 65 \\
\hline KS027 & 61 & 1.53 & 34 & 66 \\
\hline KS028 & 63 & 1.70 & 34 & 68 \\
\hline KS033 & 75 & 2.92 & 35 & 76 \\
\hline KS036 & 74 & 2.83 & 35 & 76 \\
\hline KS041 & 58 & 1.37 & 36 & 65 \\
\hline KS042 & 42 & 0.69 & 41 & 57 \\
\hline KS011 & 52 & 1.08 & 34 & 56 \\
\hline KS012 & 56 & 1.26 & 36 & 60 \\
\hline KS022 & 63 & 1.67 & 37 & 67 \\
\hline KS024 & 62 & 1.58 & 37 & 68 \\
\hline KS030 & 74 & 2.81 & 47 & 75 \\
\hline
\end{tabular}

Explanations: $\% \mathrm{Na}$ - sodium total percentage, $\mathrm{KR}$ - Kelly's ratio, $\mathrm{MH}$ - magnesium hazard indicator, PI - permeability index.

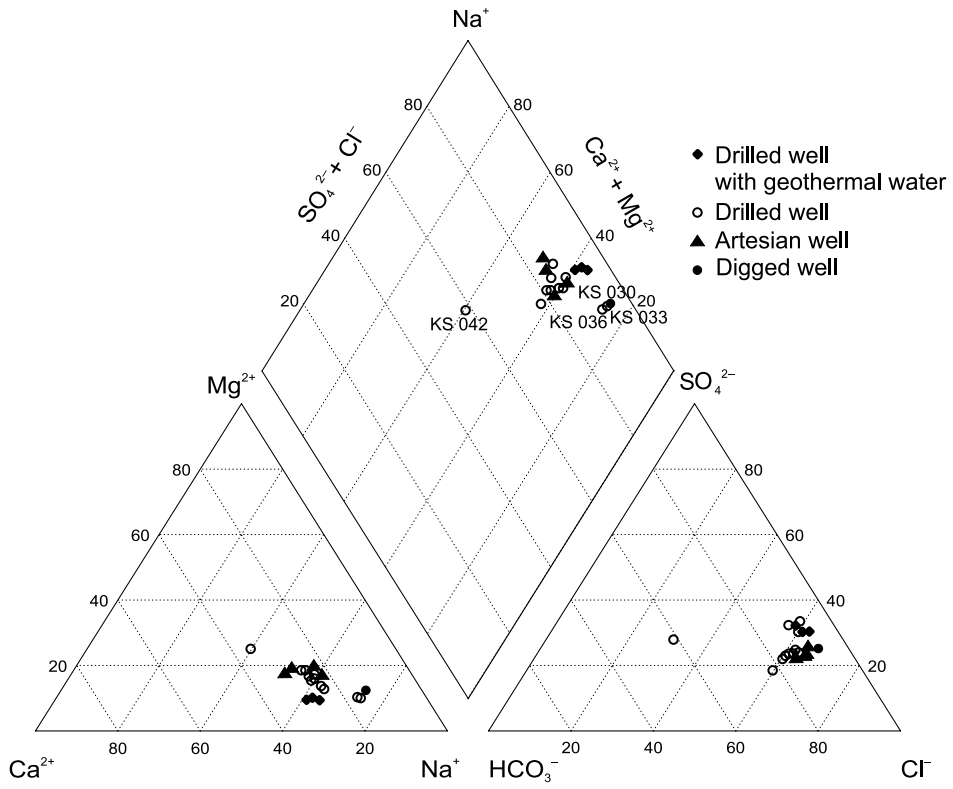

Fig. 2. Piper diagram indicating the hydrochemical type of water 
Table 4. Base exchange index of water in the tested wells

\begin{tabular}{|c|c|c|c|}
\hline ID sample & Base exchange index & ID sample & Base exchange index \\
\hline KS004 & 0.03 & KS033 & -0.25 \\
\hline KS005 & 0.01 & KS036 & -0.24 \\
\hline KS032 & 0.05 & KS041 & 0.18 \\
\hline KS002 & 0.20 & KS042 & 0.03 \\
\hline KS013 & 0.14 & KS011 & 0.19 \\
\hline KS017 & 0.15 & KS012 & 0.20 \\
\hline KS018 & 0.14 & KS022 & 0.16 \\
\hline KS026 & 0.15 & KS024 & 0.13 \\
\hline KS027 & 0.14 & KS030 & 0.00 \\
\hline KS028 & 0.13 & & \\
\hline
\end{tabular}

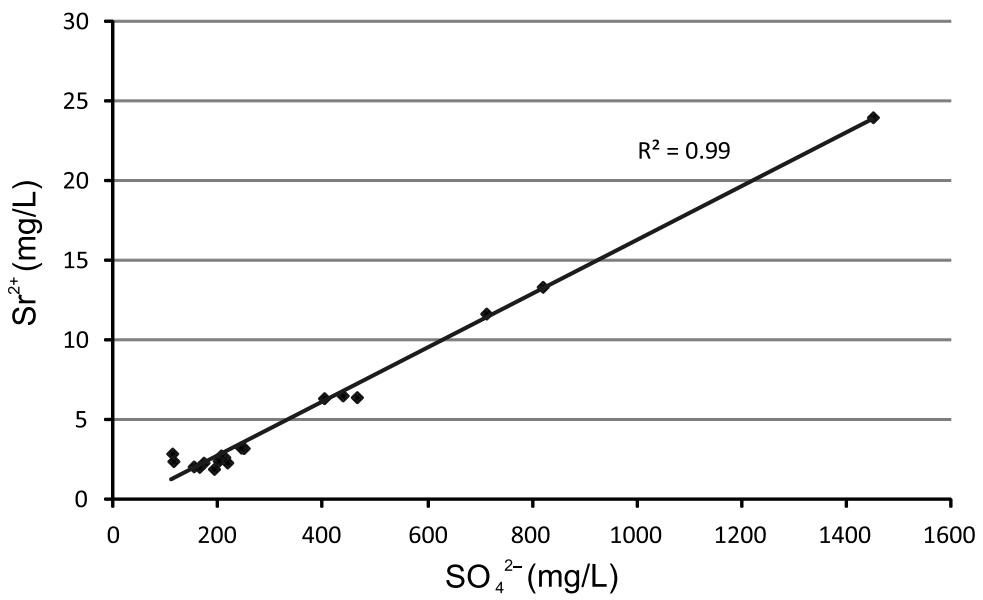

Fig. 3. Strontium versus sulfate concentrations $(\mathrm{mg} / \mathrm{L})$

presence of which in groundwater is linked to the lack of convenient wastewater treatment systems. Reduction in the content in case of wells drawing water from large depths (approximately $1500 \mathrm{~m}$ ) has been noted, while in case of more shallow wells the average value of nitrate concentration is $30 \mathrm{mg} / \mathrm{L}$ (Fig. 4). This could indicate that there are some areas with the contamination of shallow groundwater due to the excessive application of fertilizers and sewage. Similar nitrate values, in the range from 0.16 to $37.50 \mathrm{mg} / \mathrm{L}$, they were also observed in northeastern Tunisia (Houatmia et al. 2016). 


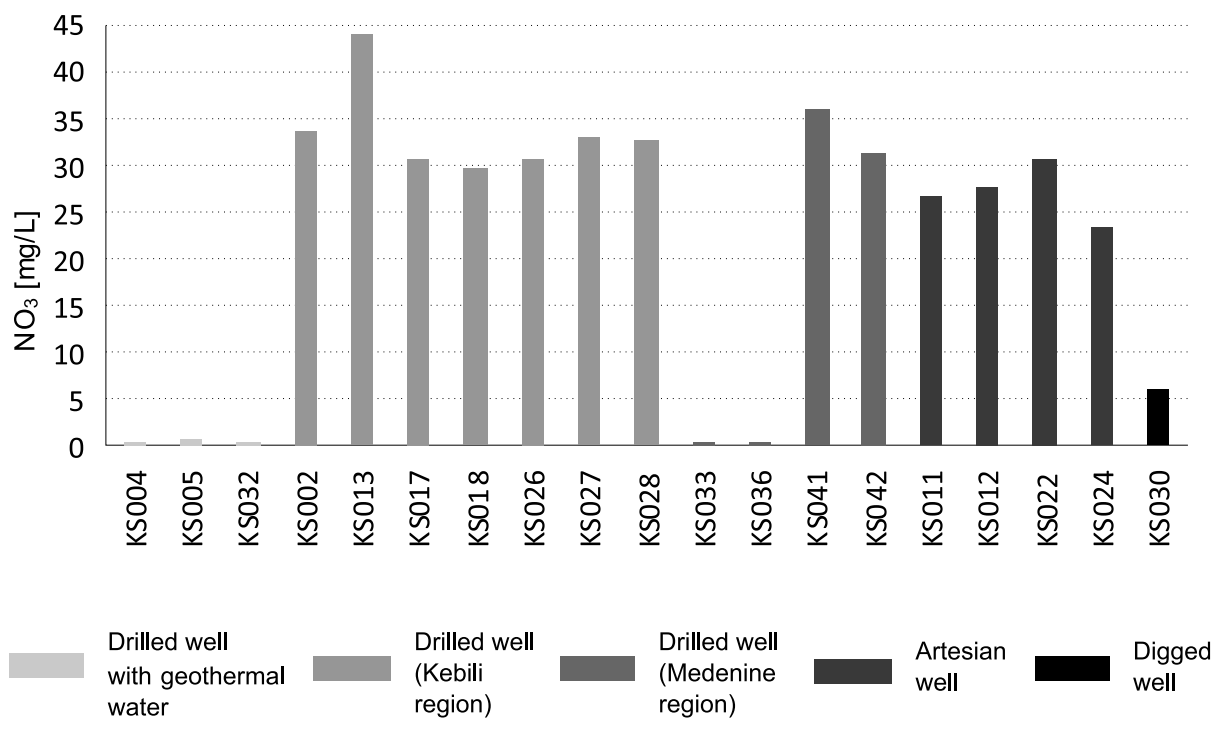

Fig. 4. Concentration of nitrates tested in water samples from the wells from the areas of Kébili and Medenine

The limited nitrate content $\left(\mathrm{NO}_{3}\right)$ indicated by the WHO is $50 \mathrm{mg} / \mathrm{L}$. None of the wells tested exceeded the specified standard but it is worth noting that these values are close to the designated standard for drinking water. The guideline value is based on short-term effects, but it is protective for long-term effects. Monitoring nitrate content is important because this value may significantly increase in the upcoming years.

Many of the tested parameters, such as $\mathrm{Li}^{+}, \mathrm{Mg}^{2+}, \mathrm{K}^{+}, \mathrm{Ca}^{2+}, \mathrm{Cl}^{-}, \mathrm{SO}_{4}^{2-}$, do not have a fixed acceptable value set by WHO. Water hardness does not affect the health aspects of its consumption, however, concentrations of $\mathrm{Na}^{+}$in excess of $200 \mathrm{mg} / \mathrm{L}$ may give rise to unacceptable taste. Among analyzed water samples 13 indicated an excessive concentration of sodium. In the case of $\mathrm{Cl}^{-}$, high concentrations of chloride give a salty taste to water and beverages. The concentration of $\mathrm{Cl}^{-}$above $250 \mathrm{mg} / \mathrm{L}$ can be easily detected in taste. It can be found in 18 of analyzed water samples. As for $\mathrm{SO}_{4}{ }^{2-}$, even though there is no limit value for this parameter, it is highly recommended that the concentration of sulphates does not exceed $500 \mathrm{mg} / \mathrm{L}$ due to possible problems with the human digestive system. The excess of the specified value has been observed three times in the analyzed water. Aluminium, chromium and copper ions found in the tested water do not exceed the following limit values specified by the WHO: $0.9 \mathrm{mg} / \mathrm{L}, 0.05 \mathrm{mg} / \mathrm{L}$ and $2 \mathrm{mg} / \mathrm{L}$ respectively. 
Groundwater in both regions was classified in terms of suitability for irrigation. Nonetheless, it should be stressed that despite the low suitability the arid climate area is still able to produce plants which have adapted to water with a high degree of salinity, often reaching above $2.5 \mathrm{mg} / \mathrm{L}$. An example of this is the Neglet Nour date palm famous in the Kébili region. Also olive trees, that are one of the main cultures in Medenine region, are moderately tolerant to salinity. Their tolerance for irrigation with salt water is even higher in case of proper management of saline water (Melgar et al. 2012). Classification of water for its suitability for irrigation can be found in Table 5. Taking into account the PI index, the values are in the range of 25-75 classifying water as suitable for irrigation. The same refers to the MH index, where the values are below 50 and thus the water is classified as suitable for irrigation. However, if we consider the $\% \mathrm{Na}$ and $\mathrm{KR}$ indexes, the majority of the water sampled exceeds the values of 60 and 1 respectively, classifying water as unsuitable for irrigation.

Table 5. Suitability of water from Kébili and Medenine for irrigation purposes

\begin{tabular}{|c|c|c|c|}
\hline $\begin{array}{c}\text { Sodium total percentage } \\
(\% \mathrm{Na})\end{array}$ & $\begin{array}{c}\text { Kelly's ratio } \\
(\mathrm{KR})\end{array}$ & $\begin{array}{c}\text { Magnesium hazard } \\
(\mathrm{MH})\end{array}$ & $\begin{array}{c}\text { Permeability index } \\
(\mathrm{PI})\end{array}$ \\
\hline Permissible and doubtful & $\begin{array}{c}\text { Unsuitable } \\
\text { (except well no KS042) }\end{array}$ & Suitable & Moderate \\
\hline
\end{tabular}

The index, which is frequently used to assess the agricultural suitability of water, is SAR. The tested water indicated values from 1.8 in well KS042 to 14.7 in well KS033, whereas in 16 of water samples the values are below 9, which classifies the water as permissible for irrigation. In one well, which was the shallowest dug well the SAR index was 21.4.

SAR, as well as EC, are classified together on the Wilcox diagram (Fig. 5). Figure 5 shows the classification of tested water with the use of the Wilcox diagram. According to the classification the water belongs to all $\mathrm{S}$ classes from low to very high sodium hazard. In terms of salinity hazard the water belongs to the group C3 and C4, i.e. to the water of a high and very high salinity hazard. According to the other authors (Prinz and Loeper 2008; Hassine et al. 2013), the salinity of Kébili region varies between 2,500 to $8,300 \mathrm{mS} / \mathrm{cm}$. Depending on the season, salinity hazard can vary, lowering in the winter, when farmers use less water and increasing in the summer, showing a positive correlation with water pumping (Marlet et al. 2008). 


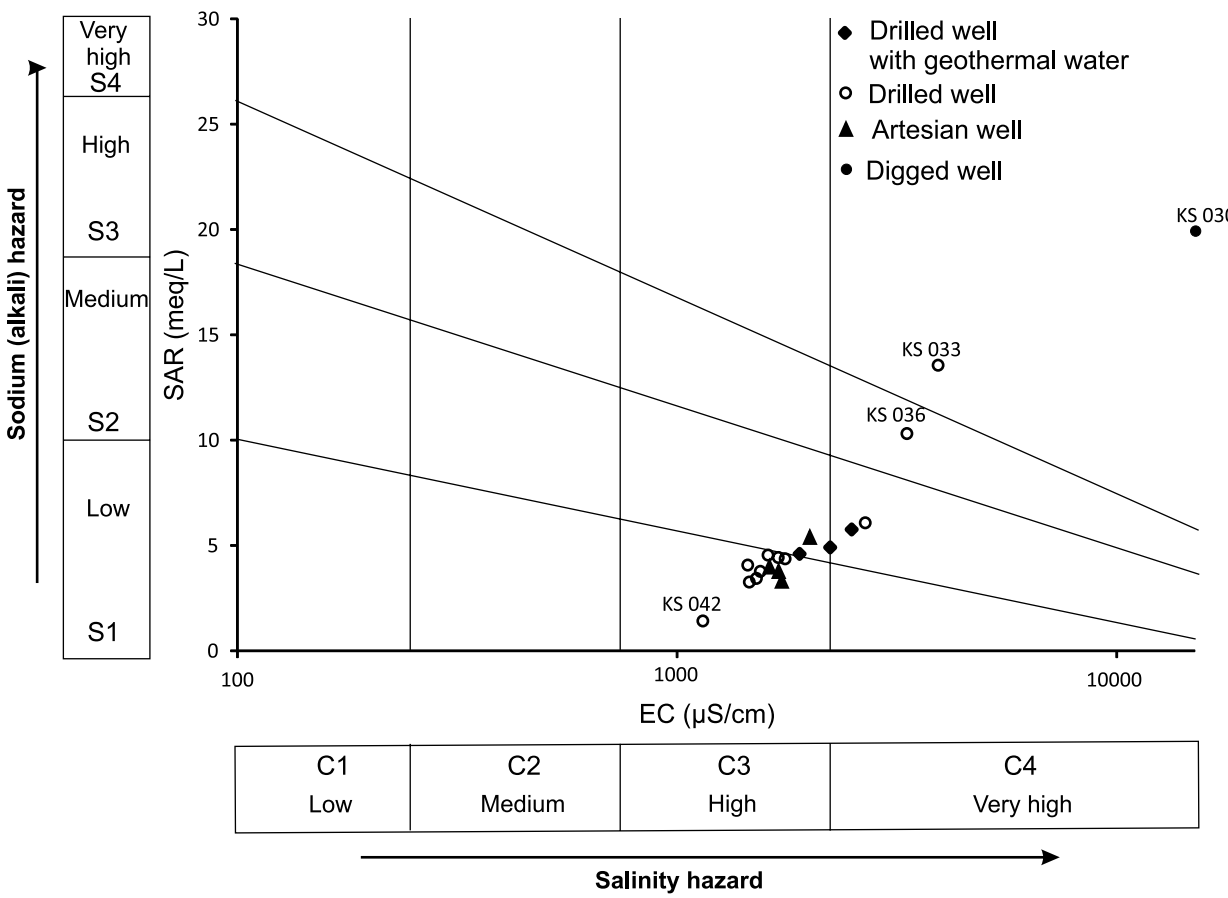

Fig. 5. SAR and EC parameters classified together on the Wilcox diagram

\section{Conclusion}

The population growth and expansion of arable land, related with the increasing demand for water, contribute to the need for increased drilling. Since the state is not able to satisfy the needs of the local population, some of the wells come from inhabitants' initiatives. Due to the effect of pumping water, its quality is decreasing. In hot and arid zones it is mainly linked with the risk of increased water salinity, therefore the possibilities to use this water for consumption or for irrigation purposes are limited. Research conducted mainly in the areas of Kébili and Medenine indicate salinity in drawn water. Base on the SAR index, a high risk of salinity and alkalinity has been shown. Salinity indicators, such as sodium total percentage $(\% \mathrm{Na})$ and Kelly's ratio (KR), also classify utility water as limited or unsuitable for irrigation. Furthermore, the water is characterized by an abnormal content of iron compounds that influence the organoleptic properties and thus are detrimental to the taste and colour of water. The nitrate content should be underlined as well. The concentration in many wells came close to the standard of $50 \mathrm{mg} / \mathrm{L}$ established by WHO. However, 
the obtained results suggest the need to continue monitoring water in the region and pay particular attention to the presence of nitrogen compounds in groundwater.

\section{Acknowlegments}

This research was financed from the budgetary funds for science for the years 2016-2019, as a research project within the "Diamond Grant" programme (grant no. 0035/DIA/2016/45) and by the National Science Centre, Poland in the frame of the project entitled "Environmental determinants of migration from countries of North Africa" (grant no. 2014/13/D/HS4/03644). The authors wish to thank Mr Adel Ben Hamed and Mr Mohamed Moujahed for their help during field studies.

\section{References}

Abdallah F., Noumi Z., Touzard V., Belgacem A.O., Neffati M., Chaieb M., 2008, The influence of Acacia tortilis (Forssk.) Subsp. raddiana (Savi) and livestock grazing on grass species composition, yield and soil nutrients in arid environments of South Tunisia, Flora-Morphology, Distribution, Functional Ecology of Plants, 203(2), 116-125.

Agoune A., 2000, Exploitation of the continental intercalaire aquifer at the Kebili geothermal field, Tunisia, United Nations University Geothermal Training Programme Tech Rep (2), 1-27.

Agoune A., 2016, Hydrogeological characteristics of the geothermal transboundary aquifer reservoir case study of the Continental Intercalaire Aquifer System in North Sahara Aquifer System (NSAS) in Southern Tunisian Field, International Journal of Environmental Science and Toxicology Research, 4(4), 54-60.

Alaya M.B., Khouni R., Zemni T., Khmeri S., \& Zargouni F., 2016, A multicriteria approach to study genesis of salted groundwater, Northern Jeffara (South-eastern Tunisia), LARHYSS Journal, (28), 103-119.

Boulbaba A., Lazzez M., Ben Rabah R., Najet S., 2012, Variations of natural soil salinity in an arid environment using underground watertable effects on salinization of soils in irrigated perimeters in South Tunisia, International Journal of Geosciences, (3), 1040-1047.

Charef A., Guedes A., Noronha F., Sousa M., 2009, Fossil and present-day hydrotermal fluids from North Tunisia: an example of a dynamic fluid evolution, Cadernos Lab. Xeolóxico de Laxe Coruña, (34), 43-58.

Ciaccio L.L., 1971, Water and water pollution, $1^{\text {st }}$ edn., Marcel Dekker Inc., New York.

Diekkrüger B., Busche H., Klose A., Klose S., Rademacher C., Schulz O., 2012, Impact of Global Change on hydrology and soil degradation - scenario analysis for the semi-arid Drâa catchment (South Morocco) [in:] Bogardi K.J., Leentvar J., Nachtnebel H.P (eds.), River basins and Change, GWSP and UNESCO-IHE, 21-26.

Dłużewski M., 2004, Charakterystyka fizycznogeograficzna obszaru szott Dæ̇erid [Physico-geographical characteristics of the Chott Jerid region] [in:] Dłużewski M. (eds.), Geomorphological workshops - Tunisia, 15-29.04.2004, WGiSR, SGP, Warsaw. 
Drouhin G., 1953, Incidences de l'utilisation des eaux souterraines sur l'équilibre hydrologique, Actes Coll. sur l'Hydrologie de la zone aride, Ankara, 129-137.

Farhat B., Mammou A.B., Kouzana L., Chenini I., Podda F., De Giudici G., 2010, Groundwater chemistry of the Mornag Aquifer System in NE Tunisia, Resource Geology, (60), 377-388.

Gouskov N., 1952, Le problème hydrogéologique du bassin artésien de l'oued R'hir. XIXe Congr. géol. Int., t. II, Algier.

Hamzaoui-Azaza F., Ketata M., Bouhlila R., Gueddari M., Riberio L., 2011, Hydrogeochemical characteristics and assessment of drinking water quality in Zeuss-Koutine aquifer, southeastern Tunisia, Environmental Monitoring and Assessment, 174(1-4), 283-298.

Härdle W.K., Simar L., 2003, Applied multivariate statistical analysis, Springer-Verlag, Berlin, Heidelberg, New York, Springer Science \& Business Media.

Hassine H.B., Slimane A.B., Mlawah M., Albouchi L., Gandouzi A., 2013, Effects of underground water on soil salinity and dates production in Kebili Oases Area (Tunisia): The case of El Bahaier Oasi, Journal Of Environmental Science, Toxicology And Food Technology, (4), 51-58.

Hem J.D., 1985, Study and interpretation of chemical characteristic of natural water, Third Edition, U.S. Geological Survery Water-Supply Paper 2254, Department of the Interior, US Geological Survey.

Houatmia F., Azouzi R., Charef A., Bédir M., 2016, Assessment of groundwater quality for irrigation and drinking purposes and identification of hydrogeochemical mechanisms evolution in Northeastern, Tunisia, Environmental Earth Sciences, 75(9), 746.

Kelly W.P., 1963, Use of saline irrigation water, Soil Science, 95(6), 385-391.

Lachaal F., Mlayah A., Anane M., Bédir M., Tarhouni J., Leduc C., 2013, Comprehension and hydrogeological conceptualization of aquifer in arid and semi-arid regions using integrated hydrogeological information system: case of the deep aquifer of Zéramdine-Béni Hassen (east-central Tunisia), Arabian Journal of Geosciences 6(7), 2655-2671.

Le Houerou H., 2010, Restoration and rehabilitation of arid and semiarid mediterranean ecosystems in North Africa and West Asia: A review, Arid Soil Research and Rehabilitation 2010, 14 (1), 184-189.

Lézine A.M., Hély C., Grenier C., Braconnot P., Krinner G., 2011, Sahara and Sahel vulnerability to climate changes, lesson from Holocene Hydrological data, Quaternary Science Reviews, (30), 3001-3012.

Marlet, S., Bouksila, F., Mekki, I., Benaissa, I., 2007, Fonctionnement et salinité de la nappe de l'oasis de Fatnassa: arguments géochimiques [in] M. Kuper, A. Zaïri (eds.), Economies d'eau en systèmes irrigués au Maghreb. Actes du troisième atelier régional du projet Sirma, Nabeul, Tunisie, 4-7 juin 2007, Cirad, Montpellier, France.

Mekki I., Jacob F., Marlet S., Ghazouani W., 2013, Management of groundwater resources in relation to oasis sustainability: The case of the Nefzawa region in Tunisia, Journal of Environmental Management (121), 142-151.

Melgar J.C., Mohamed Y., Serrano Castillo N., García-Galavís P.A., Navarro C., Parra M.A., Beltrán G., Benlloch M., Fernández-Escobar R., 2012, Response of olive trees to irrigation with saline water, ISHS Acta Horticulturae 949: VI International Symposium on Olive Growing. 
Mouldi B.M., 2003, Multiple integrated use of geothermal resources in the Kebili region, southern Tunisia [in:] International Geothermal Conference, Reykjavík, 14-17 September 2003, 11-21.

Peel M.C., Finlayson B.L., McMahon T.A., 2007, Updated world map of the Köppen-Geiger climate classification, Hydrology and Earth System Sciences Discussions , 4(2), 439-473.

Piper A.M., 1944, A graphic procedure in geochemical interpretation of water analyses, Transactions, American Geophysical Union, 25, 914-923.

Prinz D., Loeper T., 2008, Nutzung fossilen Grundwassers in der tunesischen Oasenwirtschaft. Efizienz - Notwendigkeit - Sinnhaftigkeit. Presentation 21.02.2008, BGR Hannover.

Ragunath H.M., 1987, Groundwater, 2nd edn, Wiley Eastern Ltd, New Delhi.

Rahaingomanana N., 1999, Water chemistry characteristics in small reservoirs of semiarid Tunisia [in:] Rain water harvesting and management of small reservoirs in arid and semiarid areas, ORSTOM/Hydromed-SARECNFR-Lund Univ., Lund, Sweden 29 June-2 July, 1998, Report 3222, 95-106.

Szabolcs I., Darab C., 1964, The influence of irrigation water of high sodium carbonate content of soils [in:] Proceedings of $8^{\text {th }}$ international congress of ISSS, transmission, 2, 803-812.

Tawadros E., 2011, Geology of North Africa, CRC Press.

Timm N.H., 2002, Applied multivariate analysis, Springer Verlag Inc., New York, USA.

Warner N., Lgourna Z., Bouchaou L., Boutaleb S., Tagma T., Hsaissoune M., Vengosh A., 2013, Integration of geochemical and isotopic tracers for elucidating water sources and salinization of shallow aquifers in the sub-Saharan Drâa Basin, Morocco, Applied Geochemistry (34), 140-151.

WHO, 2017, Guidelines for drinking-water quality: fourth edition incorporating first addendum, Geneva.

Zammouri M., Siegfried T., El-Fahem T., Kriâa S., Kinzelbach W., 2007, Salinization of groundwater in the Nef:awa oases region, Tunisia: Results of a regional-scale hydrogeologic approach, Hydrogeology Journal, 15(7), 1357-1375.

Beata Latos

Institute of Geophysics

Polish Academy of Sciences

01-452 Warsaw, Poland

latos.bee@gmail.com

Karolina Sobczak-Szelc

University of Warsaw

Centre of Migration Research

Pasteura 7, 02-093, Warsaw, Poland

k.sobczak-szelc@uw.edu.pl

Krzysztof Skocki

University of Warsaw

Centre of Migration Research

Pasteura 7, 02-093, Warsaw, Poland

krzysztof.skocki@wp.pl
Rafat Koztowski

Jan Kochanowski University

Department of Environment Protection and Modeling ul. Świętoktorzyska 15, 25-406 Kielce, Poland rafal.kozlowski@ujk.edu.pl

Anna Szczucinska - corresponding author Adam Mickiewic: University in Poznań Faculty of Geographical and Geological Sciences ul. Krygowskiego 10, 61-680, Poznań, Poland szana@amu.edu.pl 